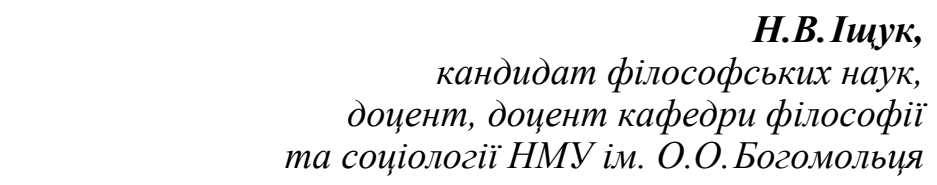

\title{
ФЕНОМЕН СПІЛКУВАННЯ В РЕЛІГІЙНО-ФІЛОСОФСЬКІЙ ТРАДИЦІЇ
}

Однією 3 можливих парадигм оновлення сучасного православного богослов'я, в руслі якої осмислюють дійсність такі визначні мислителі та церковні діячі, як І.Зізіулас, Х.Яннарас, А.Сурозький, $є$ богослов'я спілкування (євхаристичне богослов'я). Незважаючи на те, що цей напрям не являє собою цілісної завершеної теологічної лінії, його адепти послідовно обстоюють такі ідеї: визнання онтологічної значимості спілкування для божественного внутрішньоіпостасного співбуття; визнання цієї значимості для особистісної екзистенції та оживотворення людського буття через входження людини в спілкування з Богом; первинність богоспілкування порівняно 3 богопізнанням тощо. Важливо, що, розглядаючи богослов'я спілкування, ми маємо на увазі не тільки нове інтелектуальне віяння в середовищі кліру, але й закономірний виток осмислення подвигу «життя у Бозі» в світлі останніх здобутків філософської думки. Семантично близьким до декількох основних концептів парадигми богослов'я спілкування є філософія діалогу, репрезентована постатями М.Бубера, М.Бахтіна, Е. Левінаса та ін.

Зосередимося на розгляді спільних для богослов'я спілкування та філософії діалогу концептів «спілкування», «діалогу», діалектики «Я - Ти», «відкритості», «зустрічі», окреслюючи спільне смислове поле їі значень.

На нашу думку, теоретичним підгрунтям парадигми спілкування в загальнокультурному контексті $€$ філософія діалогу. Звертаючись

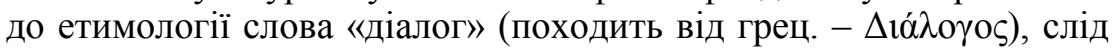

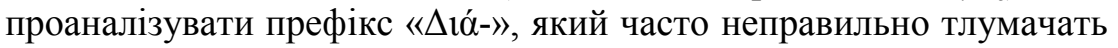
у прочитанні « $\Delta \mathrm{t}-»$ («подвійний», «двічі»). Тобто діалог розуміється в значенні словесної взаємодії між двома особами. Український дослідник і представник філософії діалогу В. Малахов наголошує на іншому смисловому ядрі цього терміна. На його думку, префікс 


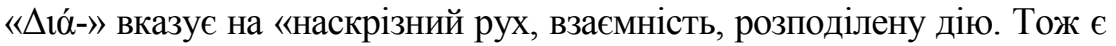
підстави розуміти «діалог» радше як розподілений логос (розподілену мову, слово, смисл), або як те, що перетинає межі окремого логосу, пов'язуючи його з іншим(и)» $[13,11]$. Тобто серце процесу діалогу - у виході поза межі монадологічної, атомарної свідомості в напрямі до Іншого. Його головна функція - трансцендентування, перенесення буття в інтерсуб'єктивний простір «Між», у якому можливе порозуміння та співбуття. Мета діалогу - створення певної міжособистісної сфери спільних смислів.

Філософія діалогу «визріла» з антропологічної інтуїції про недосконалість, недостатність монадологічного існування людини. Зосереджена лише на собі самій, потрапляючи в тенета самотності, людина зрештою відчуває неповноту буття. Це й спонукає її виходити на пошуки Іншого, його взаємності. Якщо йдеться про Бога як найвизначнішого Іншого, з яким можна вступити в діалог чи долучитися до розмови, або принаймні постояти в світлі Його слів, в парадигмі богослов'я спілкування постає питання про Іншого як про гаранта онтологічного статусу «Я». Тобто людське «Я» існує в усій повноті лише завдяки спілкуванню з Богом.

Звернемося до творів чільного представника філософії діалогу М.Бубера, зосередившись на тих ключових моментах, котрі вплинули на інтелектуальне тло, в світлі якого започатковується традиція богослов'я спілкування. На думку названого філософа, спосіб людського буття від початку має дуальний характер. Стосунки «Я» та «Ти» діалектичні за своєю природою, тобто кожна з осіб, залучених до спілкування, визначає одна одну. «Стаючи Я, людина стає Ти» [7, 44], - пише М.Бубер. Визнаючи «Ти», «Я» запрошує його стати не об'єктом цілераціонального маніпулювання, а рівноправним суб'єктом взаємності.

Справжнє спілкування передбачає граничну відкритість, а отже, і вразливість суб'єктів, що наважуються вступити у взаємодію. Інший стає «Ти» для «Я», що зацікавлений ним, готовий до співпраці, визнає його як гідного учасника стосунків. «Діалог не обмежується спілкуванням двох людей одного з одним, він... є стосунком людей одного до одного, що виражається в їхньому спілкуванні» $[8,129]$. Тобто спілкування не зводиться до вербальних комунікативних актів, а лише певною мірою може виявлятися через них. Саме тому ми обминаємо увагою надбання як трансцендентальної комунікативної філософії, так і семіотики та аналіти- 
ки мови. Нас цікавить не так сенс повідомлення та умови його передання, як природа взаємодії співрозмовників.

Співзвучними до ідей М.Бубера є думки Е. Левінаса. Поділяючи вихідну тезу про діалогічність людської природи, останній констатує можливість виходу в царину діалогу, де «Я» визначається через акт дарування себе «Ти», який і визначає його сутність. Початок його розмірковувань - звернення до досвіду повсякденності. Кожен iз нас народжується в спільноті. В ній розгортається наше непроблематичне існування, тобто ми «закинуті» в соціальне буття і сприймаємо його членів (промовляємо «Ти») навіть швидше, ніж сприймаємо самих себе (кажимо «Я»). Е. Левінас пише: «...однак я не є іншим. Я - це я сам. Моє буття, той факт, що я існую, - мій акт існування - становить дещо абсолютно неперехідне, безінтенційне, безвідносне. Істоти можуть обмінятися між собою всім, окрім свого акту-існування. Тією мірою, якою я $\epsilon$, я є монадою» $[11,28]$. Тобто людина з'являється у світі окремою одиницею, монадою, визначеною в термінах окремішності та самотності лише завдяки самому акту свого матеріального, тобто тілесного, існування.

Ця проблема, на думку Е. Левінаса (і тут він погоджується 3 М.Бубером), долається завдяки трансцендентуванню. Проте Інший, якого ми зустрічаємо в соціальному світі, постає передовсім як оречевлений Інший, «інший вже через одяг постає у світі річчю» $[12,23]$. Така репрезентація вигідна Іншому, адже робить його менш вразливим в актах соціальної взаємодії, а отже, убезпечує від страждання. Тому більшість соціальних контактів - поверхові й інструментальні, в яких кожна 3 двох самотностей намагається утвердити свою самобутність одна завдяки іншій. Ця проблема долається через вихід у царину інтерсуб'єктивності, в якій інший уже буде не одягненою річчю, а розквітне у своїй інакшості. «Інший - це ближній, але близькість - це не деградація чи етап злиття. У взаємності, що притаманна для цивілізованих стосунків, забувається асиметричність інтерсуб'єктивного зв'язку. Цивілізована взаємність - це царство цілей, де кожен одночасно і мета, і засіб...» $[12,60]$. Тобто автентичне спілкування знімає проблему домінування одного над іншим, закладену в природі асиметричних стосунків, а взаємність як основа такого спілкування передбачає, що кожна з осіб визнає пріоритет іншого понад власним.

Здійснимо невеликий відступ, зазначивши, що аналогічним чином проблема спілкування осмислюється не тільки філософією 
діалогу, а й, наприклад, російською релігійною філософією. Зокрема, М.Бердяєв констатує, що визначальною характеристикою людського буття $\epsilon$ трансцендентування за власні межі в царину міжособистісного спілкування. Трансцендентування - це спосіб, завдяки якому людина, залишаючи себе, зрештою повертається до себе справжньої, подолавши власну вроджену атомарність завдяки диву спілкування. «Моє життя трансцендентує себе. Але це трансцендентування робить болісним і хворобливим моє існування, оскільки «Я» залишаюся в світі. «Я» тільки й існує, оскільки воно себе трансцендентує. Воно перестає існувати, залишаючись у собі безвихідним... Але «Я» отримує своє існування лише тому, що трансцендентує себе, у внутрішньому існуванні своєму виходить до іншого і до інших, до «Ти», до іншої людини, до Божого світу. Немає нічого огиднішого й руйнівнішого, аніж коли «Я» егоцентрично занурене в себе і в свої стани, забувши про інших...» $[6,267]$. Відтак центром особистісного буття має бути Інший поза суб'єкт-об'єктним тлумаченням, як жива істота, чиї страждання і любов існують для того, щоб бути розділеними.

Звернемо увагу на православний концепт спілкування. Він глибоко вкорінений в тринітаристиці, яка закладає парадигму співбуття іпостасей Бога в собі, Бога та людини, людини та людини однією з одною через Бога, Бога і християнської спільноти людей. Теологічне тлумачення спілкування передбачає взаємне відношення Бога до людини та людини до Бога, засноване на принципах діалогічності як «зустрічі двох», переживанні присутності та зв'язку з Іншим. Звідси - розвинута персонологія спілкування, яка, описуючи взаємодію між Богом та людиною, доводить iї конституювальне значення для людської особистості.

Екстраполюючи окреслені нами під час розгляду філософії діалогу ідеї, спинимося на схожості секулярної парадигми інтерсуб'єктивності та православної парадигми перихорезису (грець. -

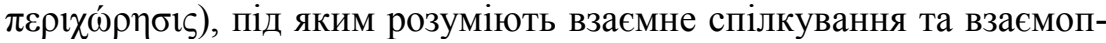
роникнення іпостасей Божественної Трійці. Поняття перихорезису спільнокореневе 3 грецьким «хорос», що семантично перегукується зі словами «зібрання», «сонм», «хор», «хоровод», і саме в такому значенні перихорезис - це хоровод любові Осіб Божественної Трійці [14]. Трійця, що водночас є нероздільною Одиницею, перебуває у взаємній єдності любові. «Кожна з Осіб Трійці живе не для Самої Себе, а без лишку віддає Себе іншим Іпостасям, залишаючись при цьому повністю відкритою для їхньої відповіді, тож всі 
три співперебувають у любові одна до одної. Життя Божественних Осіб - це взаємопроникнення, життя однієї Особи стає життям Іншої. У такий спосіб буття Бога Трійці здійснюється як любов, в якій власне існування особи ототожнюється із віддаванням Себе двом іншим» [9].

Так само, як грецькі Отці Церкви стверджували про апофатичність пізнання Божественної Триєдності, ми не можемо дати позитивну якісну оцінку характеристикам чи рисам Осіб Трійці. Більше того, якби ми спробували так учинити, це призвело б до втрати унікальності кожної з Осіб, перетворило б особистість на конгломерат обчислюваних властивостей, підвело під спільний знаменник чи категорію «не порівнюване». «Будь-яке визначення - це обмеження», як казав Б.Спіноза. На перший погляд, такий підхід до дослідження природи особистісності тільки віддаляє нас від зрозумілих та артикульованих визначень, переносить суб'єкт у сферу туманного трансцендентного. Однак, як зазначає І. Зізіулас, це єдиний прийнятний підхід до окресленої проблеми. «І коли йдеться про Бога, i коли йдеться про людину, ідентичність особистості визнається та стверджується ясно і недвозначно, але це уможливлюється лише у стосунках і через стосунки, а не посередництвом об'єктивної онтології, в якій ідентичність ніби ізольована, визначена та описана сама по собі. Особистісна ідентичність буде повністю втрачена, якщо іiі ізолювати, бо ж іï онтологічні умови - це стосунки». [10, 143]. Отже, визначення Осіб Божественної Трійці уможливлюється завдяки стосункам, в яких вони перебувають одна з одною.

Фактично категорія особистісного спілкування наділяється онтологічними конотаціями. Спілкування виводить особистість у царину дійсного буття, конституює її сутність. Водночас будь-який спосіб спілкування, який відкидає чи принижує особистість, тим самим заперечує її буття. В момент автентичного спілкування особа утверджує як своє буття («Я $\epsilon$, бо мене почуто»), так і буття свого співрозмовника. Парадоксально, але саме у стосунках 3 iншим викристалізовується сутність та ім'я особистості. Так, імена Осіб Божественної Трійці вказують на їх ставлення одне до одного. «Спільна поява божественної природи з тринітарним буттям, що ініційоване Отцем, вказує на те, що Отець також «віднаходить»... божество лише «остільки, оскільки» з'являються Син та Дух (без них Він не може мислитися як Отець)» $[10,180]$. Про автентичну особистісність Триєдиного Бога нам відомо досить мало. Проекції 
людської особистості на божественну практично безплідні. У цьому контексті важливими є прозріння екзистенціалістської філософіï, бо засвідчують незадоволеність людини своїм станом та мірою зростання, підкреслюють спрагу кожного 3 нас віднайти свою справжню особистість. Натомість, замість накидання Богові своєї природи, варто зробити протилежне: вмовчатися в глибини Божества і дати Йому відкрити нам свою справжню особистісність.

Що ж передує боголюдському спілкуванню «Я - Ти»? Один із визначних представників православної духовності митр. А.Сурозький так описує феномен «поклику», який спонукає людину долучатися до спілкування і життя в Бозі. «Віра наша, якщо вона виростає в реальність, повинна починатися з голоду, 3 туги, з пошуку чи 3 дива зустрічі... У кожній людині є така глибина, такий обшир, які ніщо не здатне заповнити; такий простір та така глибина, які можуть бути заповнені лише Божою присутністю. У цю глибину, в цю безодню ми можемо кидати все, що земля може дати: і знання, і красу, i живі почуття; проте наша душа ніколи не буває до кінця задоволена, залишається голод, туга, бажання... Такий голод пробуджує в душі людини усвідомлення того, що чим завгодно можна поступитися лиш для того, щоб знайти... Того Єдиного, Хто може заповнити й преобразити душу, тіло, всю істоту» [1, 23-24]. Тобто людині іманентно властива спрага за Творцем, що спонукає іiі шукати Його, вслухатися в Його слово і з нетерпінням чекати Його відповіді.

Інший, що вже набрав досвіду спілкування та досяг єднання 3 Богом, і тримається за нього як за щось найбільш істинне у своєму житті, «живе у Бозі», може стати для неофіта ликом, іконою Божою в дії. Адже ми живемо в епоху, віддалену в часі від моменту Боговтілення, і маємо покладатися на свідчення Священного Писання та Священного Передання, а не на досвід особистої зустрічі iз втіленим Христом. Тож таким ликом Божим для того, хто ще тільки на шляху до пізнання Творця, стає інший. «Ми зустрічаємо людей, які знають Христа, вірують у Нього. Як каже старе прислів'я: ніхто не може зректися всього, щоб слідувати за Богом, якщо не побачить в обличчі хоч однісї людини сяйва вічного життя... Іноді людина сяє. Іноді ми бачимо в людині таку глибину і такий обшир любові, самозабуття, що вона вже землі не належить. Вона нам розкриває початок небесного» $[2,16] .3$ одного боку, згадувана порожнеча, яка не може наповнитися нічим іншим, окрім Бога, змушує сотвореного за образом шукати гранично пра- 
вдивого сенсу життя. 3 другого, досвід зустрічі з іншим, що вже долучився завдяки досвіду Богоспілкування до спільноти вірних, відповів ствердно на поклик відповідати Його подобі, впевнює в реальності жаданої зустрічі з Трансцендентним Іншим.

Переживши відчуття присутності Божої у власному житті та впевнившись на особистому досвіді в реальності Христа, людина усвідомлює відповідальність, яку накладає цей факт на ії майбутнє. Адже тепер вона щомиті бачить той справжній зразок, зважаючи на який вона має здійснювати кожен наступний учинок. I цим зразком $є$ Христос. Втративши відчуття спілкування з Богом, але будучи впевненою в тому, що цей минулий досвід - реальність та істина, людина потребує рішучості, відваги поставити перед собою мету і не відступати від правди, яку було обрано. А отже, отримати шанс стати живою іконою Божою.

Перебуваючи в стані пильності до іншого і відкидаючи нав'язливу тваринну стурбованість собою, така людина стикається 3 наступною перешкодою - із власною неміччю, з безсиллям, слабкістю і кволістю духу. Проте в немочі людській прославляється велич Божа, адже усвідомлення власного безсилля може спонукати людину стати гранично відкритою і гнучкою в руках Божих, дати Йому засяяти через себе, віддатися на Його волю. «І починаючи такий день, ми повинні увійти в глибоке спілкування з Богом, вмовчатися у наші власні глибини в Його присутності» [3, 47]. Вмовчатися, щоб почути, а почути, щоб душею відгукнутися, розділити почуте і змінитися, переродитися в автентичну особистість. Здається, нема нічого простішого й очевиднішого, проте розділити почуте означає відкритися і прийняти його, а значить, можливо, прийняти біль і страждання іншого, співстраждати з ним. Відкритість таїть у собі потенційну можливість стати вразливим, а це небезпечно.

Проте потенційне страждання, що супроводжує відкритість іншому, можна і варто тлумачити, за митр. А.Сурозьким, як необхідну умову вдосконалення душі. Адже в ситуації комфорту людина зупиняється на досягнутому і докладає всіх сил для того, щоб залишатися в ньому, власноруч консервуючи своє життя. Голод, холод, біль, страждання і співчуття виводять душу зі стану сонної рівноваги, спонукають іï досягати закладеного в ній божественного зразка. В одній з бесід митр. А.Сурозький каже про те, що випробування і спів-страждання, що можуть супроводжувати автентичну розмову з іншим, - це ті умови, які дозволять душі «вирости в іiі 
повну міру» [5, 98], прямувати до досягнення тотожності 3 тією подобою, що закладена в кожному з нас споконвіку.

Наполегливо тримаючись за істинність досвіду присутності Бога у власному житті, зміщуючи симетрію уваги 3 «Я» на «Іншого», реалізуючи імператив відкритості та вчування в його слово, людина отримує можливість стати суб'єктом автентичного спілкування. «Будь-яка зустріч може стати зустріччю під Божим покровом, може стати зустріччю, протягом якої я маю щось принести іншому чи маю щось від іншого отримати. I тому, якщо ми до кожної зустрічі, до кожної події нашого життя будемо ставитися так, що стане можливим - як би не складалося, що б не сталося - не втрачати зв'язку з Богом» $[3,54]$. Так кожна людина була б образом Божим, а служіння їй - служінням Христу.

Транслюючи істини православної традиції, митр. А.Сурозький каже про те, як через Слово Господь сотворив світ, покликав його до буття в акті вільної любові, знаючи наперед, що він відпаде і повинен буде бути відкуплений дорогою ціною - стражданням і смертю Його Сина. Такою потужною була Божа інтенція любові, спрямована до сотвореної людини. Бог породив людину з небуття, аби вона могла вступити, розділити та стати автентичним учасником Таїнства спільної з Ним любові. Такою сильною, пише митр. А.Сурозький, була Божа віра в людину.

Як же людина може на неї відповісти, знаючи, що Бог простягав руку любові до людини до крайньої межі, аж до самої смерті. «Відповідаючи на це, ми можемо відгукнутися лише благоговінням, вдячністю, любов'ю та готовністю всі сили - нехай вони будуть малі, але всі без залишку - докласти до того, щоб Божа хрестова любов не залишилася без відповіді, щоб хресна смерть Христа Спасителя не була нами забута та відкинута» $[4,142]$. Відповідь людини це цілісіньке ії життя, прожите з вдячністю та благоговінням; життя, розцінюване як дар, а не як даність; життя як шанс $з$ небуття перейти в життя вічне.

\section{Висновки:}

Підсумовуючи, варто ще раз підкреслити, що з позиції філософії діалогу та богослов'я спілкування автентична зустріч «Я» та «Ти» передбачає моменти відкритості, зміщення акценту з промовляння на слухання (та 3 егоцентричної стурбованості собою «Я» до вчування в слова «Ти»), співчуття та чуйність. У такій розмові 
Інший дає поштовх «Я» для того, щоб воно могло вирости повною своєю мірою. Прибічники філософії діалогу погоджуються 3 цими моментами. Проте, на думку мислителів, яких ми залічуємо до означених напрямів релігійно-філософської думки, діалог «Я» та «Ти» набуває нового змісту завдяки тому, що звучить в присутності Трансцендентного Іншого. Його Слово - дороговказ і зразок, а досвід стояння перед Ним, вчування в Його відповідь стає мірилом спілкування з будь-ким іншим. Щодо теоантропологічних перспектив, то теологічним аналогом інтерсуб'єктивності є перихорезис - православна парадигма взаємного спілкування та взаємопроникнення іпостасей Божественної Трійці, що богослов'ям спілкування екстраполюється на особистість людини, посилюючи тринітарні мотиви в іiі розумінні. 3 феноменологічного погляду спілкування, в розглянутих контекстах, не можливе без відкритості, очікування, туги, поклику та відповіді, через які й здійснюється уся повнота співбуттяспілкування людини з Богом та іншими людьми.

\section{ЛIТЕРАТУРА}

1. Антоний (Блум), митр. Сурожский. О путях веры. Пути христианской жизни. Беседы. - К., 2001. - 272 с. - С. 20-39.

2. Там само. - С.13-19.

3. Там само. - C.40-62.

4. Там само. - С. $140-163$.

5. Там само. - C.87-116.

6. Бердяев Н. А. Я и мир объектов. Опыт философии одиночества и общения // Бердяев Н.А. Философия свободного духа. - М., 1994. - С.230-316.

7. Бубер М. Я и Ты // Бубер М. Два образа веры. - М., 1999. - С. 124-121.

8. Там само. - С. $122-161$.

9. Давыденков О. Иерей. Догматическое богословие. Курс лекций. http://www.mediaglagol.com.ua/book/12_edinosuschie_lits_presvyatoyi_troitsy

10. Зизиулас И. Общение и инаковость. Новые очерки о личности и Церкви. M., 2012. -407 c. - C. 180.

11. Левинас Э. Время и другой. Гуманизм другого человека. - СПб., 1998. - C. 23-118.

12. Левинас Э. От существования к существующему // Левинас Э. Избранное. Тотальность и Бесконечное. - М., 2000. - С. 7-63.

13. Малахов В. Етика спілкування. - К., 2006. - 400 с.

14. Филоненко А.C. Богословие общения и евхаристическая антропология. - http://www.bogoslov.ru/text/876935.html. 
Іщук Н.В. Феномен спілкування в релігійно-філософській традиції.

Стаття присвячена окресленню паралелей між парадигмами філософії діалогу та богослов'я спілкування через зіставлення їх ключових концептів та ідей. Обгрунтовується когерентна лінія їх «розгортання», що виявляється в посиленні несубстанціалістського підходу до людської особистості з позицій важливості Іншого для іїі конституювання. 3'ясовується, що 3 позицій як філософії діалогу, так і богослов'я спілкування автентична зустріч «Я» та «Ти» має своєю передумовою моменти відкритості, зміщення акценту з промовляння на слухання, співчуття та чуйність. Проте в богослов’ї спілкування діалог «Я» та «Ти» набуває нового змісту завдяки присутності Трансцендентного Іншого. Розглядаються теоантропологічні перспективи перихорезису (теологічного аналога інтерсуб'єктивності) та посилення тринітарних мотивів у розумінні особистості в сучасній православній теології. Окреслено феноменологію спілкування, в іiї секулярному та теологічному контекстах, а також єдність відкритості, очікування, туги, поклику та відповіді, через які й здійснюється уся повнота співбуттяспілкування людини з Богом та іншими людьми.

Ключові слова: богослов'я спілкування, інтерсуб'єктивність, перихорезис, поклик, зустріч, відкритість, діалог «Я» та «Ти», Інший як ікона.

Ищук Н.В. Феномен общения в религиозно-философской традиции.

Статья посвящена выявлению параллелей между парадигмами философии диалога и богословия общения через сопоставление их ключевых концептов и идей. Обосновывается когерентная линия их развития, что проявляется в усилении несубстанционалисткого подхода к человеческой личности с позиций важности Другого для ее конституирования. Доказывается, что с позиций как философии диалога, так и богословия общения аутентичная встреча «Я» и «Ты» предусматривает моменты открытости, смещения акцента с речи на слушание, сочувствие и отзывчивость. В богословии общения диалог «Я» и «Ты» приобретает новое содержание благодаря тому, что звучит в присутствии Трансцендентного Другого. Рассматриваются теоантропологические перспективы перихорезиса (теологического аналога интерсубъективности) и усиление тринитарных мотивов в понимании личности современной православной теологией. Описана феноменология общения, в ее секулярном и теологическом контекстах, а также единство открытости, ожидания, тоски, зова и ответа, вследствие чего и осуществляется вся полнота события-общения человека с Богом и другими людьми.

Ключевые слова: богословие общения, интерсубъективность, перихорезис, зов, встреча, открытость, диалог «Я» и «Ты», Другой как икона. 
Ishchuk N.V. The phenomenon of communication in religious and philosophical tradition.

The article is devoted to outlining the parallels between the paradigms of philosophy of dialogue and theology of communication through the comparison of their key concepts and ideas. On the basis of the works of such representatives in philosophy of dialogue as M. Buber, E. Levinas and the representatives of theology of communication in its orthodox version A. Surozhskiy and I.Zizioulas, a converged line of their «deployment» has been justified. This is reflected in transferring of their ideas of an erroneous, incomplete and monadological human existence, which urges him to seek Other, who is the guarantor of the ontological status of «I». As a result, there is made an apology of non-substancialist approach to human personality from the position of the importance of relationships with Other for its constitution. It turns out that from the standpoint of both philosophy of dialogue and theology of communication the authentic meeting of «I» and «You» provides moments of openness, a shift from pronouncing to listening, compassion and sensitivity. However, in theology of communion the dialogue between «I» and «You» takes on a new meaning because of the fact that it sounds in the presence of the Transcendental Other - God. From these positions, the prospects of theoanthropological perichoresis are considered (a theological analogue of the intersubjectivity paradigm) and strengthening of trinitarian motifs in understanding of personality in contemporary Orthodox theology. The article outlines phenomenology of communication in its secular and theological contexts: the unity of openness, expectation, sadness, call and answer, which are carried through the fullness of communication of man with God and other people. By example of the concept of A. Surozhskiy human experiences of these states are shown: from openness and call to «life in God» and the meaning of Other as an icon for man's approaching to the depths of the divine co-existence.

Key words: theology of communication, intersubjectivity, perichoresis, call, meeting, openness, the dialogue of «I» and «You», Other as an icon. 